\title{
Character Building in Full Day School, Extracurricular and Student Athletes
}

\author{
Alan Alfiansyah Putra KaroKaro \\ Postgraduate Study Program Sport Education \\ UniversitasNegeri Medan, \\ Medan, Indonesia \\ alanalfiansyahputra@ymail.com
}

\author{
Albadi Sinulingga \\ Faculty of Sport Science \\ UniversitasNegeri Medan \\ Medan, Indonesia
}

\author{
Rahma Dewi \\ Postgraduate Study Program Sport Education \\ UniversitasNegeri Medan \\ Medan, Indonesia
}

\begin{abstract}
In 2045, Indonesia will get a demographic bonus of $70 \%$ of Indonesia's population. It is hoped that the Indonesian population at that time will excel, advance and be able to compete with other nations, as well as mature enough to overcome the issues of classical national problems, such as corruption, poverty and so on.In addition to family and society, school is one place in shaping character. Intelligence alone is not enough in dealing with these demands, but character is also a very important thing to realize a dream of a golden Indonesia. In terms of character formation, education takes an important role in this matter. Character education can be done in families, communities and schools. The purpose of this study was to determine the formation of characters at full day school, extracurricular and student athletes.This study uses literature study research methods on Full Day School, Extracurricular, and Student Athletes. Based on this, Full Day School, Extracurricular and Student Athletes have a role in character building.
\end{abstract}

Keywords : Character.Education. School

\section{INTRODUCTION}

In 2045, Indonesia will get a demographic bonus, namely the population of Indonesia is $70 \%$ in productive age (15-64 years), who excel, advance to compete with other nations, and are mature enough to overcome the issues of the nation's classic problems, such as corruption, poverty and so on. While the remaining $30 \%$ is an unproductive population (under 14 years and over 65 years) in the period 2020-2045[1].

Intelligence alone is not enough in dealing with these demands, but character is also a very important thing to realize a dream of a golden Indonesia. In terms of character formation, education takes an important role in this matter. Character education can be done in families, communities and schools.

Schools are one place in shaping character, schools are considered capable of successfully improving the quality of life of students not only measured by numbers but also by their character, attitude and way of thinking. They are not only able to read and count, but they are expected to be able to analyze the problems of life in the future so that children can account for all decisions taken for their lives and also character education through school, not only learning knowledge, but more from that, namely the cultivation of morals, ethical values, aesthetics, noble character and so forth.

At the age of 6-18 years the social development of students is very much influenced by the school environment. Furthermore, junior high school students are in the stage of developing identity vs. role confusion. At this stage students are at the stage of seeking their identity, starting to appear to hold social roles in society but not yet able to organize and separate tasks in different roles [2].

The education process in Indonesia is regulated by the State. The education process in Indonesia is based on a formal foundation, namely the Republic of Indonesia Law no. 20 of 2003 concerning the National Education System with the aim of developing the potential of students to have the intelligence, personality and noble character of being healthy, knowledgeable, capable, creative, independent, and a democratic and responsible citizen. Not only forms an intelligent Indonesian human being, but also a personality that grows and develops with a character that respects the noble values of the nation and religion [3].

\section{METHOD \& RESULT}

This study uses literature study research methods on Full Day School, Extracurricular, and Student Athletes. Based on this, Full Day School, Extracurricular and Student Athletes have a role in character building.

\section{A. Character}

Character is something that qualifies a person. Character becomes identity, characterizes, becomes a fixed trait, which overcomes the ever-changing contingent experience. So character is a set of values that have become a habit of life so that it becomes a permanent characteristic in a person, for example hard work, never give up, honest, simple, etc [4].

Character is a psychological nature, character or character that characterizes a person or group of people [5]. Character can also be interpreted as attitudes, character, character, stable 
personality as a result of the process of consolidation progressively and dynamically [6].

Based on some of the above understanding, it can be concluded that the character is the quality or strength of mental and moral, character or individual character that reflects the individual's personality in particular which is the driving force or driving force, and which distinguishes from other individuals.

\section{B. Full Day School}

Full day school comes from English, which is full meaning full, day means day, while school means school [7]. So the definition of full day school is school throughout the day or the teaching and learning process that is applied from morning to evening, from $06: 45$ to $15: 30$ WIB, with a duration of rest every two hours. Thus, the school can arrange the lesson schedule freely, adjusted to the weight of the subjects and added to the deepening of the material. The main thing in full day school is the arrangement of subject schedules and deepening[8].

Full day type school lasts almost a full day, from 8:00 a.m. to 3:00 p.m.". Thus, a full day school system is a component that is organized regularly and well to support the human maturation process (students) through teaching and training efforts with longer or longer school time compared to schools in general [9]. Minister of Education and Culture MuhadjirEffendy stated that the Full day school policy is for students to study for eight hours a day with the expansion of material carried out with co-curricular and extracurricular activities with the implementation not necessarily in school [10]. Based on the explanation above, the researchers concluded that full day school is a school that organizes full day learning from morning to evening with some of its time used for learning programs that are informal and fun for students, student activities in school, good learning, playing, worship packed in cognitive, affective and psychomotor learning whose implementation does not have to be in school.

Full day school, besides aiming to develop the quality of education, the most important is full day school aims to be one of the efforts to foster students' faith and morals and instill positive values. Full day school also provides a strong foundation in learning in all aspects, namely intellectual, physical, social and emotional development. Because in a full day school system, schools have a longer time than conventional primary schools in general.

\section{Exstracurricular}

Extracurricular activities are activities carried out inside develop certain aspects of what is found in the curriculum that is being run, including the ones related to how true application of science knowledge learned by participants students in accordance with the demands of needs their lives and the environment surrounding it. Extracurricular activities education outside of class hours shown to help development of students, accordingly with needs, potential, talent, and their interest through activities specifically organized by students and or energy capable and education authorize at school [11].

Extracurricular activities are educational activities outside the subjects to help the development of students in accordance with their needs, potential, talents, and interests through activities that are specifically organized by educators and / or educational staff who are capable and authority in schools / madrasas [12].

Extracurricular activities can be interpreted as educational activities conducted outside face-to-face class hours. These activities are carried out inside or outside the school environment hours in order to broaden knowledge, improve skills, and internalize the values or rules of Religion as well as social norms, both local, national and global to form a complete human being [13].

Based on the expert opinion above the researchers draw the conclusion that extracurricular is an additional student learning hours outside the normal time of school which aims to develop and foster students' interests and talents, in order to expand knowledge, improve skills, and internalize the values or rules of religion as well as social norms, both local, national and global.

In carrying out extracurricular activities must have a goal to be achieved, as for the purpose are:

a. Adding and expanding students' knowledge of subjects or material obtained during extracurricular activities.

b. Develop students' talents and interests in personal development efforts.

c. Towards a whole human being.

d. Improving students' abilities as members of the community in conducting reciprocal relationships in the social, cultural and universe environment.

e. Train discipline, honesty, trust and responsibility in developing tasks.

f. Increase understanding of Islamic religion so that it can develop itself in accordance with religious norms and be able to practice the development of science, technology and culture.

g. Develop Islamic morality that integrates relationship with God S.W. T, the apostle and man even with himself.

h. Develop students' sensitivity in seeing social, religious issues so that they become proactive people towards social problems and da'wah.

i. Give students the opportunity to have the ability to communicate well, verbally and non-ferbally.

j. Train students' ability to work as well as possible independently or in groups.

k. Develop students' abilities in everyday problems [14].

\section{Athelete Students}

Sports activities depend on the attitude of someone from which they interpret them. If some people say that exercise is a necessity because it is related to awareness of health, there are also those who view that sports as a means of communication for affiliation, this happens a lot in gymnastic clubs, where it has become a trend to come to clubs whose purpose other than to increase fitness is also a place to socialize.

The essence of the word athlete is also expressed a lot by experts. athletes are subjects or someone who works or pursues a particular sport and achieves in the sport [15]. athletes are sportsmen, especially in fields that requires strength, agility, 
and speed [16].) athletes are people who take part in the match to pit their strengths to achieve an achievement [17].

Based on the opinions of some experts, it can be concluded that the athlete is someone who engages in sports that require strength, agility, and speed and participating in the match complements his ability to achieve an achievement.

\section{CONCLUSION}

Schools are one place in shaping character, schools are considered capable of successfully improving the quality of life of students not only measured by numbers but also by their character, attitude and way of thinking. They are not only able to read and count, but they are expected to be able to analyze life problems in the future so that children can account for all decisions taken for their lives.

Character is the quality or strength of mental and moral, character or individual character that reflects the personality of the individual specifically who is a driver or driver, and that distinguishes from other individuals.

A full day of school, in addition to aiming to develop the quality of education, the most important thing is that a full-day school aims to be one of the efforts to foster students' faith and morals and instill positive values. Full day school also provides a strong foundation in learning in all aspects, namely intellectual, physical, social and emotional development. Because in a full day school system, schools have a longer time than conventional primary schools in general.

Extracurricular is an additional student learning hours outside normal school time which aims to develop and foster students' interests and talents, in order to broaden knowledge, improve skills, and internalize the values or rules of Religion as well as social norms, both local and national or globally.

An athlete is someone who engages in a sport that requires strength, agility, and speed and participates in matches competing for his ability to achieve an achievement.

\section{References}

[1] https://www.goodnewsfromindonesia.id/2017/11/21/indonesia-bisalahirkan-generasi-emas-bukan-micindiakses 17 juli 2018.

[2] Dalam buku Direktorat Jendral Guru dan Tenaga Kependidikan Kemendikbud (2016:11).

[3] Undang-Undang Nomor 20 Tahun 2003. Tentang Sistem Pendidikan Nasional. Jakarta: Depdiknas.

[4] Sutarjo Adisusilo.2013. Pembelajaran Nilai Karakter. Jakarta: PT. Raja Gravindo Persada.

[5] Abdul Majid, Dian Andayani. 2010. Pendidikan Karakter dalam Perspektif Islam. Bandung: Insan Cita Utama.

[6] Yahya Khan. 2010. Pendidikan Karakter Berbasis Potensi Diri: Mendongkrak Kualitas Pendidikan. Yogyakarta: Pelangi Publishing.

[7] Echols, John M. and Shadily, Hassan. 1976. Kamus InggrisIndonesia, cet.XXVI. Jakarta, PT Gramedia Pustaka.

[8] Baharuddin. 2010. Pendidikandan Psikologi perkembangan. Jogjakarta: Ar-Ruzz Media.

[9] Sulistyaningsih, Wiwik. 2008. Full Day School dan Optimalisasi Perkembangan Anak. Yogyakarta: Paradigma Indonesia.
[10] https://edukasi.kompas.com/read/2016/08/08/12462061/ini.alasan.me ndikbud.usulkan.full.day.school. diakses 20 Juni 2018.

[11] Wiyani, NovanArdy. 2013. Menumbuhkan Pendidikan Karakter di SD (Konsep, Praktekdan Strategi). Jogjakarta :Ar-Ruzz Media.

[12] Anifral Hendri. 2008. Ekskul Olahraga Upaya Membangun karakter Siswahttp://staff.uny.ac.id/sites/default/files/132313281/semornas\%20fi k\%20uny\%20(Faidillah\%201). pdf diakses 24 Mei 2018.

[13] ZainalAqib, Sujak. 2011. Panduan dan Aplikasi Pendidikan Karakter. Bandung: Yrama Widya.

[14] Tarsa. 2003. Basic Kompetensi Guru. Jakarta: Depertement Agama Republik Indonesia.

[15] Basuki Wibowo.2002. Kamus Besar Bahasa Indonesia. Jakarta: Balai Pustaka.

[16] Salim, Peter dan Salim, Yenny, 1991, KamusBehasa Indonesia Kontemporer, Jakarta :Modern English Press.

[17] Miftakhul Jannah. 2012. Peran Konsentrasi, Kepercayaan diri, Regulasi Emosi, Kemampuan Goal Setting, dan Persisten Terhadap Prestasi Pelari Cepat 100 Meter Perorangan 